\title{
KETERAMPILAN MENGINTERPRETASIKAN HASIL PENIMBANGAN PADA KMS TERKAIT PENGETAHUAN, PELATIHAN DAN KEAKTIFAN KADER DI KOTA BOGOR
}

\author{
Suhartika, Ni Wayan Dian Ekayanthi \\ Poltekkes Kemenkes Bandung, Prodi Kebidanan Bogor, Jl. Dr. Sumeru No. 116 Bogor Jawa Barat \\ Email: tika02fr@gmail.com
}

\begin{abstract}
Skills Interpreting Result of Learning Result in KMS Related to Knowledge, Training and Performance of the Kader in the City Of Bogor
\end{abstract}

\begin{abstract}
Kartu Menuju Sehat (KMS) is a card that contains the child's normal growth curve based on anthropometry indices weight for age. The purpose of this study was to investigate the relationship between knowladge, training and activity with cadres skill in interpreting the results of weighing the KMS toddler in Puskesmas Bogor Barat, Bogor. This research is an analytic research with cross sectional study design. The samples are met the inclusion criteria with systematic random sampling technique amounted to 51 people. The results based on the analysis of statistical test by chi-square test showed that trainninghave meaningful relationships with a cadre of skills in interpreting the results of weighing the KMS toddlers. $(p=0.014)$. As for the knowladge and activity does not correlate significantly with the skills of cadres in interpreting the results of weighing the KMS toddlers. $(p=0.565$ and $p=0,209$ ).
\end{abstract}

Keywords: knowladge, trainning, activity, cadre of skill, KMS toddlers

\begin{abstract}
Abstrak: Kartu Menuju Sehat (KMS) adalah kartu yang memuat kurva pertumbuhan normal anak berdasarkan indeks antopometri berat badan menurut umur. Tujuan penelitian ini adalah untuk mengetahui hubungan antara pengetahuan, pelatihan dan keaktifan kader dengan keterampilan dalam menginterpretasikan hasil penimbangan pada KMS balita di wilayah kerja Puskesmas Bogor Barat, kota Bogor. Penelitian ini merupakan penelitian analitik dengan rancangan penelitian cross-sectional. Sampel yang digunakan adalah kader posyandu di 5 (lima) puskesmas yang memenuhi kriteria inklusi dengan tehnik systematic random sampling berjumlah 51 orang. Hasil penelitian berdasarkan analisis uji statistik dengan uji chi square menunjukkan bahwa pelatihan mempunyai hubungan yang bermakna dengan keterampilan kader dalam menginterpretasikan hasil penimbangan pada KMS balita. $(p=0,014)$. Sedangkan untuk pengetahuan dan keaktifan tidak berhubungan secara signifikan dengan keterampilan kader dalam menginterpretasikan hasil penimbangan pada KMS balita. ( $p=0,565$ dan $p=0,209$ )
\end{abstract}

Kata kunci: pengetahuan, pelatihan, keaktifan, keterampilan kader, KMS Balita

\section{PENDAHULUAN}

KMS di Indonesia telah digunakan sejak tahun 1970-an sebagai sarana utama kegiatan pemantauan pertumbuhan. Pemantauan pertumbuhan adalah serangkaian kegiatan yang terdiri dari penilaian pertumbuhan anak secara teratur melalui penimbangan berat badan setiap bulan, pengisian KMS, menentukan status pertumbuhan berdasarkan hasil penimbangan berat badan, dan menindaklanjuti setiap kasus gangguan pertumbuhan. Tindak lanjut hasil pemantauan pertumbuhan biasanya berupa konseling, pemberian makanan tambahan, pemberian suplementasi gizi dan rujukan (Kemenkes RI, 2010).

Menurut Kemenkes (2011), kader bertugas untuk melakukan penimbangan berat badan bayi, menentukan status pertumbuhan berdasarkan kurva KMS serta memberikan penyuluhan dan konseling gizi. Berdasarkan Survey Kesehatan Rumah Tangga (SKRT) tahun 2005 hanya 46,6\% 
kader posyandu yang pernah mendapat pelatihan tentang KMS. Menurut 58,6\% kader yang disurvei, penggunaan KMS adalah untuk memantau pertumbuhan balita. Akibatnya pemanfaatan KMS sebagai sarana penyuluhan gizi dinilai masih rendah.

Banyak terjadinya angka putus (droup out) ataupun pergantian kader tanpa diikuti pelatihan atau retraining menyebabkan lemahnya pengetahuan kader dalam memberikan pelayanan, salah satunya pengetahuan tentang KMS. Hal ini akan mengakibatkan kegiatan pemantauan pertumbuhan balita yang dinilai dari KMS tidak dapat dilakukan secara optimal, sehingga upaya pemantauan menjadi kurang efektif (Oktariani, 2014).

Tujuan penelitian ini adalah untuk mengetahui hubungan antara pengetahuan, pelatihan dan keaktifan kader dengan keterampilan dalam menginterpretasikan hasil penimbangan pada KMS balita di wilayah kerja Puskesmas Bogor Barat, kota Bogor.

\section{METODE PENELITIAN}

Penelitian ini menggunakan desain observasional dengan pengambilan data pada waktu sesaat dan secara bersamaan (cross sectional). Penelitian ini merupakan penelitian kuantitatif menggunakan data primer untuk mengetahui hubungan antara pengetahuan, pelatihan dan keaktifan kader dengan keterampilan dalam menginterpretasikan hasil penimbangan pada KMS Balita di wilayah kerja Puskesmas Bogor Barat. Pengambilan data dilakukan pada bulan Juni-Juli tahun 2016.

Jumlah sampel minimal diperoleh sebanyak 46 orang. Untuk mengantisipasi sampel drop out ditambah 10\% darijumlah sampel yang dihitung, jadi jumlah sampel penelitian 51 orang.

Pengambilan sampel dilakukan secara systematic random sampling di Kecamatan Bogor Barat (Puskesmas Semplak, Puskesmas Gang
Kelor, Puskesmas Pancasan, Puskesmas Pasir Mulya, dan Puskesmas Sindang Barang).

Pengumpulan data dilakukan oleh tim peneliti, melalui wawancara dan observasi. Untuk menganalisis hubungan pengetahuan, pelatihan dan keaktifan kader dengan keterampilan kader dalam menginterpretasikan hasil penimbangan pada KMS Balita dengan uji chi-square (Arikunto, 2010)

\section{HASIL PENELITIAN}

Pengetahuan, pelatihan dan keaktifan kader posyandu dapat dilihat pada tabel 1 berikut ini:

Berdasarkan tabel 1 diketahui bahwa sebagian besar subjek mempunyai pengetahuan baik yaitu 88,2\% dan tidak ada satu pun yang berpengetahuan kurang. Sebagian besar subjek juga pernah mendapat pelatihan, yaitu 58,8\% dan 98\% dari subjek penelitian aktif dalam kegiatan posyandu.

Tabel 1. Pengetahuan, Pelatihan dan Keaktifan Kader

\begin{tabular}{lcc}
\hline Variabel & n & \% \\
\hline Pengetahuan & & \\
Baik & 45 & 88,2 \\
Cukup & 6 & 11,8 \\
Kurang & 0 & 0 \\
\hline Jumlah & 51 & 100 \\
\hline Mengikuti Pelatihan & & \\
$\quad$ Pernah & 30 & 58,8 \\
Tidak Pernah & 21 & 41,2 \\
\hline Jumlah & 51 & 100 \\
\hline Keaktifan & & \\
Aktif & 50 & 98 \\
Tidak Aktif & 1 & 2 \\
\hline Jumlah & 51 & 100 \\
\hline
\end{tabular}

Tabel 2. Keterampilan Kader Posyandu

\begin{tabular}{lcc}
\hline Variabel & n & \% \\
\hline Keterampilan & & \\
Terampil & 20 & 39,2 \\
Tidak terampil & 31 & 60,8 \\
\hline Jumlah & 51 & 100 \\
\hline
\end{tabular}


Tabel 3. Hubungan Pengetahuan, Pelatihan, dan Keaktifan Kader dengan Keterampilan

\begin{tabular}{lccc}
\hline Variabel Terikat & \multicolumn{2}{c}{ Keterampilan } & \multirow{2}{*}{ Nilai $p$} \\
\cline { 1 - 3 } Variabel Bebas & Terampil & Tidak Terampil & \\
Pengetahuan & & 28 & 0,565 \\
$\quad$ Baik & 17 & 3 & \\
$\quad$ Cukup & 3 & 14 & 0,014 \\
\hline Pelatihan & & 17 & \\
$\quad$ Pernah & 16 & & \\
$\quad$ Tidak Pernah & 4 & 31 & 0,209 \\
\hline Keaktifan & 19 & 0 & \\
$\quad$ Aktif & 1 & & \\
$\quad$ Tidak Aktif & & &
\end{tabular}

Keterampilan kader posyandu dalam menginterpretasikan hasil penimbangan dapat diketahui dari Tabel 2 yang menunjukkan bahwa sebagian besar kader posyandu tidak terampil dalam menginterpretasikan hasil penimbangan pada KMS Balita, yaitu sebanyak 31 orang $(60,8 \%)$.

Berdasarkan tabel 3 dapat diketahui bahwa variabel yang mempunyai hubungan signifikan dengan keterampilan kader dalam menginterpretasikan hasil penimbangan adalah pelatihan $(\mathrm{p}<0,05)$.

\section{PEMBAHASAN}

Tingkat pengetahuan tidak berhubungan terhadap keterampilan kader dalam menginterpretasikan hasil penimbangan pada KMS balita. Perilaku yang didasari oleh pengetahuan akan lebih langgeng daripada perilaku yang tidak didasari oleh pengetahuan, namun bila dianalisis lebih jauh proses terbentuknya suatu kesadaran tidak hanya dipengaruhi oleh pengetahuan (Notoatmodjo, 2010).

Berdasarkan hasil penelitian diperoleh bahwa pelatihan memiliki hubungan yang signifikan terhadap keterampilan kader dalam menginterpretasikan hasil penimbangan pada KMS balita. Kemampuan dalam menginterpretasi hasil penimbangan dalam KMS merupakan modal dasar dalam deteksi dini gangguan pertumbuhan pada anak balita. Pelatihan adalah bagian dari pendidikan yang menyangkut proses belajar yang berguna untuk memperoleh dan meningkatkan keterampilan di luar sistem pendidikan yang berlaku, dalam waktu relatif singkat dan metodenya mengutamakan praktek daripada teori (Notoatmodjo, 1998).

Salah satu cara yang dapat dilakukan untuk meningkatkan keterampilan kader adalah melalui pelatihan. Penelitian yang dilakukan oleh Fitri (2011) menunjukkan bahwa pelatihan tentang antropometri dapat meningkatkan keterampilan kader posyandu (Fitri, 2011). Laerani (2014) dalam penelitiannyatentang pengaruh penyegaran kader dengan pre dan post test menemukan bahwa ada peningkatan keterampilan kader setelah diberikan penyegaran. Hasil penelitian ini senada dengan penelitian yang dilakukan Sistiarani (2016), yang menunjukkan bahwa ada peningkatan keterampilan kader dalam pemanfaatan buku KIA setelah diberikan pelatihan (Sistiarani, et al., 2016)

Jika interpretasi hasil penimbangan tidak tepat, maka gangguan pertumbuhan tidak dapat dideteksi secara dini, sehingga balita akan terlambat memperoleh penanganan. Hal ini sesuai yang disampaikan Prasetyawati (2012), yaitu 
KMS balita harus diisi secara lengkap dan jelas karena dampak dari ketidaklengkapan KMS adalah petugas kesehatan akan kesulitan dalam pengambilan keputusan jika terjadi penyimpangan tumbuh kembang dan status gizi pada anak balita (Prasetyawati, 2012).

Keaktifan kader tidak berhubungan dengan keterampilan kader dalam menginterpretasikan hasil penimbangan pada KMS balita. Keaktifan merupakan suatu perilaku yang bisa dilihat dari keteraturan dan keterlibatan seseorang untuk aktif dalam kegiatan. Dalam penelitian ini, keaktifan kader hanya dilihat berdasarkan jumlah kehadiran (dikatakan aktif jika kader menghadiri kegiatan posyandu $\geq 10$ kali), tidak melihat kegiatan yang dilakukan. Ada kader yang hanya bertugas di bagian pendaftaran atau penimbangan saja sehingga ada kader yang hampir tidak pernah melakukan pencatatan pada KMS. Hal ini dapat menyebabkan kurangnya keterampilan kader tersebut dalam melakukan pencatatan maupun dalam menginterpretasikan hasil pada KMS.

Hal ini sesuai dengan teori yang menyatakan bahwa salah satu faktor yang menentukan keterampilan seseorang adalah faktor situasional, menyangkut tipe tugas yang diberikan. Jika seseorang hanya diberikan tugas tertentu, maka orang tersebut hanya akan terampil mengerjakan tugas yang diberikan dibandingkan dengan tugas yang lain (Mamun, 2000).

\section{PENUTUP}

Berdasarkan hasil penelitian dapat disimpulkan bahwa pelatihan merupakan variabel yang mempunyai hubungan yang signifikan dengan keterampilan kader dalam menginterpretasikan hasil penimbangan pada KMS Balita.

Saran yang disampaikan dari hasil penelitian ini adalah perlunya persyaratan minimal pendidikan untuk menjadi kader, rotasi kegiatan di posyandu, dan penelitian lanjutan tentang faktor-faktor lain yang berhubungan dengan keterampilan kader dalam menginterpretasikan hasil penimbangan (status $\mathrm{N}$ dan $\mathrm{T}$ ) pada KMS Balita.

\section{DAFTAR PUSTAKA}

Kementerian Kesehatan RI. (2010). Peraturan Menteri Kesehatan No.155 tentang Penggunaan Kartu Menuju Sehat bagi Balita. Jakarta: Kemenkes RI.

Kementerian Kesehatan RI. (2011). Pedoman Umum Pengelolaan Posyandu. Jakarta: Kemenkes RI

Octariani Silva, dkk. (2014). Hubungan Antara Tingkat Pengetahuan Dengan Pengisian KMS Balita Di Desa Jetak Dan Samirono Kecamatan Getasan Kabupaten Semarang. Artikel Ilmiah. Online. Diunduh dari: http:// perpusnwu.web.id/karyailmiah/documents/ 3792.pdf tgl 22 oktober 2014

Arikunto, S. (2010). Prosedur Penelitian: Suatu Pendekatan Praktik. Jakarta: Rineka Cipta:

Notoatmodjo, S. (2010). Pendidikan dan Perilaku Kesehatan. Jakarta: Rineka Cipta.

Notoatmodjo, S. (1998). Pengembangan Sumber Daya Manusia. Jakarta: Rineka Cipta.

Fitri, H., Mardiana. (2011). Pelatihan terhadap Kader Posyandu. Jurnal Kesehatan Masyarakat. Vol.7(1):22-7.

Laraeni Y, Wiratni A. (2014). Pengaruh Penyegaran Kader Terhadap Pengetahuan dan Keterampilan Kader Posyandu Menggunakan Dacin di Wilayah Kerja Puskesmas Dasan Cermen Kecamatan Sandubaya Kota Mataram. Jurnal Media Bina Insani. ISSN No. 1978-3787. Volume 8 No. 4 Juli 2014.

Sistiarani, C., Kurniawan, A., Dardjito, E. (2016). Impact of Health Volunteer Training to Improve Utilization of Maternal Child Health 
(MCH) Book In Kalibagor Indonesia. International Journal of Public Health and Clinical Sciences Vol. 3 (3): 103-11.

Prasetyawati, AE. (2012). Kesehatan Ibu dan Anak (KIA) dalam Millenium Development Goals (MDG'S). Yogyakarta: Nuha Medika.

Mamun, A., Saputra, Y. (2000). Perkembangan Gerak dan Belajar Gerak. Jakarta: Depdikbud. 